\title{
Impact of Cataract Surgical Services in Ogun State, Nigeria
}

\author{
Tayo J Bogunjoko1*, Adekunle O Hassan1, BGK Ajayi , Olufemi Oderinlo,, Ogugua Okonkwo ${ }^{1}$, \\ Abimbola Ashaye ${ }^{1}$,Toyin Akanbi ${ }^{1}$, Steve Mukiri ${ }^{1}$, Ayo Akinye ${ }^{1}$ and Ejike Egbu ${ }^{2}$
}

Eye Foundation Centre for the Prevention of Blindness Ilese-ljebu-Imushin, Ogun state, Nigeria

St Mary's Catholic Eye Hospital, Ago-Iwoye, Ogun state, Nigeria

${ }^{*}$ Corresponding Author: Tayo J Bogunjoko, Eye Foundation Centre for the Prevention of Blindness, Old Lagos-Benin-Ore Road, Ilese/ljebu-Imushin, Ogun state, Tel: 23481 69691105; E-mail: tayo.bogunjoko@eyefoundationhospital.com

Received date: November 15, 2016; Accepted date: December 30, 2016; Published date: January 06th, 2017

Citation: : Bogunjoko TJ, Hassan AO, BGK Ajayi, Oderinlo O, Okonkwo O, et al. (2017) Impact of Cataract Surgical Services in Ogun State, Nigeria. J Eye Cataract Surg 3:16. doi: 10.21767/2471-8300.100016

Copyright: (C) 2017 Bogunjoko TJ, et al. This is an open-access article distributed under the terms of the Creative Commons Attribution License, which permits unrestricted use, distribution, and reproduction in any medium, provided the original author and source are credited.

\section{Abstract}

Background: Cataract remains the principal cause of blindness globally at $51 \%$. The cataract surgical rate (CSR) in developed countries is about 4000 to 6000 while in most part of Africa and other developing countries it is $400-500$. Cataract backlog and low cataract surgical rate is a constant feature in Nigeria as in other parts of Africa and Asia.

Objective: to determine the impact of cataract surgical services in Ogun state of Nigeria.

Methods: This was a cross-sectional study whereby the operation registers for the period of one year (1st January to 31st December 2014) at the Eye Foundation Centre (EFC), St Mary's Catholic Eye Hospital (SMCEH) Ago-Iwoye, Babcock University Eye Clinic and all the state hospitals in Ogun state were reviewed. The numbers of operable cataracts (eye with $<6 / 24$ due to cataract) in the outreach and clinic registers were noted. The number of eyes operated for age-related cataracts were determined. This research did not consult patients. The name of the surgeon per cataract surgery was noted and number of surgeons per clinic or hospital compiled. Information on Ogun state population was obtained. Cataract backlog and cataract surgical rate in the state were assessed.

Results: A total of 8660 operable cataracts were identified and 5410 eyes were done during this period leaving a backlog of 3250 eyes (in this study). Cataract surgical rate for Ogun state for the period was 1098 operations per million per year. The main providers of cataract surgical services in Ogun state are Eye Foundation Centre 3099 eyes (57.2\%) and St Mary's Catholic Eye Hospital 1951 (36.0\%), totalling 5050 eyes (93.2\%). Others did 360 eyes (6.8\%). There are 18 surgeons in the state but 11 participated in the study. Therefore an average of 491 cataract operations is performed by an ophthalmic surgeon per year in Ogun state.

Conclusion: Cataract surgeries of 5410 performed annually in the state is more than the incidence of cataract blindness in the state which is estimated at 4924 . CSR of 1098 is more than the universally accepted cataract blindness incidence of 1000 per million populations per year for developing countries. Therefore, if these figures are surpassed in the coming years with more improved cataract services delivery, the backlog will be drastically reduced.

Keywords: Cataract; Eye; Surgical; Blindness; Ophthalmic; Diseases; Ophthalmologist

\section{Introduction}

As at 2010, The World Health Organisation estimates that 285 million people globally suffers from vision loss (blindness and visual impairment). Of this 39 million are blind (best corrected visual acuity less than $3 / 60$ in the better eye with best available correction) and 246 million have low vision (vision less than $6 / 18$ ). Cataract remains the principal cause of blindness at $51 \%$ [1]. The number of cataract surgery performed per million populations per year is called cataract surgical rate (CSR) [2-4]. Developed countries perform about 4000 to 6000 cataract surgeries per million populations per year $[5,6]$. In most part of Africa and other developing countries, CSR is about 400-500 $[7,8]$. One of the exceptions is in developing countries is India which has a CSR of 5000 [9].

Cataract backlog and low cataract surgical rate is a constant feature in Nigeria as in other parts of Africa and Asia [6-8]. The Nigerian National Blindness survey identified cataract as the commonest cause of severe visual impairment (SVI) and blindness being responsible for $45.3 \%$ and $43.0 \%$ respectively [10]. "Operable" cataract affects 400,000 people. By 2020 , the number of adults with operable cataract will increase by $43 \%$ to 600,000 assuming that the incidence of SVI and blindness due to cataract and cataract surgical coverage remain essentially unchanged over the next 12 years [10]. The estimated population of Ogun state in 2014 is 4,924,929 [11,12]. With a prevalence of blinding cataract of $0.5 \%$ [5], therefore 24,624 are estimated to be blind in Ogun state. About $80 \%(19,699)$ are blind from age-related cataract, in Ogun state. Assuming the incidence of cataract blindness of $1000 /$ million population per 
year [5,6], 4924 persons become blind per million populations per year.

Nigeria is one of the countries in West Africa made up of 178 million people (2014 estimated) [13]. It is made up of 36 states plus the federal capital territory Abuja.

Ogun state is one of the 36 states that make up Nigeria. It is located in the southwest zone of Nigeria with a population of 3.7 million (2006 national census) [14]. Estimated population for 2014 is 4,924,929 (UNFPA) [11,15]. It is made up of 20 local government areas with headquarter in Abeokuta. $45 \%$ of the population is urban while $55 \%$ is rural (Figures 1,2 and 3) [11].

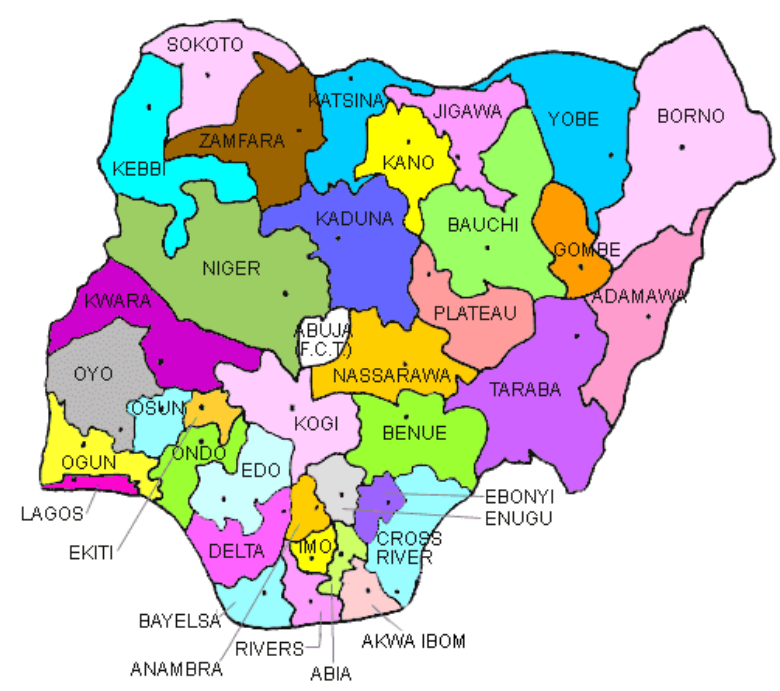

Figure 1: Map of Nigeria showing the states of the federation. Source: Nigeria official website.

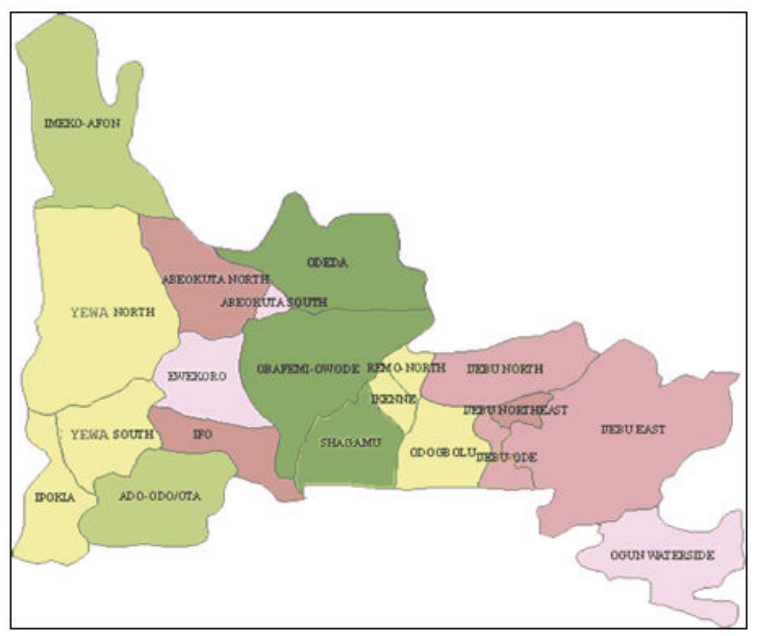

Figure 2: Map of Ogun State of Nigeria showing the 20 local governments that make up the state. Source: Ogun State official website.

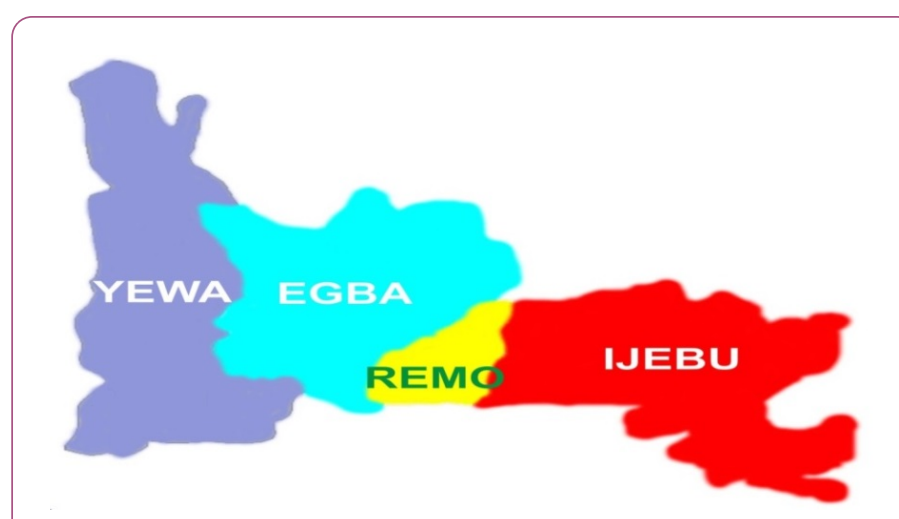

Figure 3: The 4 divisions in Ogun state.

Hilton cataract initiative $(\mathrm{HCl})$ project was established to test a social enterprise model to improve access to high quality cataract surgery in Sub-Saharan Africa [16]. Eye Foundation Centre (EFC), is one of the selected existing eye centres in SubSaharan Africa to help build capacity and reach more patients with the goal of doubling her annual output of cataract operations. One other hospital that does high volume cataract surgeries is St Mary Eye Hospital Ago-Iwoye. Other hospitals mostly do cataracts that present in the clinic. There are no organised outreach services.

There is no record or publication on cataract backlog and cataract surgical rate (CSR) in Ogun state of Nigeria. The data obtained from this study will hopefully help Ogun state and its eye care workers to plan cataract surgical services in a better way by identifying the gaps and filling it to be able to reduce avoidable blindness to the barest minimum.

The purpose is to determine the impact of cataract surgical services in Ogun state of Nigeria. The objectives are:

1. To assess the backlog of cataract

2. To assess the CSR in Ogun state

3. To assess the number of cataract surgeries per surgeon

\section{Method}

This was a cross-sectional study. All the clinics and hospitals offering cataract surgical services were approached from the record in the state ministry of health and professional bodies. Only 2 government hospitals did not accede to our request, including the private clinics, 2 in number. The data was obtained from the 2 solely eye hospitals (Eye foundation centre and St Mary's Eye Hospital), the eye clinics of the 4 state hospitals and Babcock university eye clinic. In the case of EFC, The state was mapped out into 4 divisions: Egba, ljebu, Yewa and Remo headed by an ophthalmic surgeon each whereby outreach camps are done weekly at each division to bus in cataract patients to base hospital for surgery. Data was not obtained from the eye clinic of Olabisi Onabanjo university teaching hospital (OOUTH) Sagamu and federal medical centre Abeokuta because the authorities declined the request. The clinic or outreach register was used to count number of patients who are 40 years and above with age related (operable) cataracts 
identified and recorded. Visual acuity at which cataract is operable in this study is less than $6 / 24$. The operation register was used to count the number of eyes operated in 40 years and above for age related cataract. The duration was from $1^{\text {st }}$ of January to $31^{\text {st }}$ of December 2014. As this was being done, the name of surgeon per cataract surgery was recorded. The number of ophthalmic surgeon per centre was also compiled. This was after due consent was obtained from the authorities of each hospital. This research did not consult patients.

Inclusion criteria: The age group of 40 years and above based on available evidence that blindness from cataract occur mostly in this age category. Record of age related cataracts done in all eye clinics and eye hospitals cataract surgery in Ogun state.

Exclusion criteria: Aged less than 40 years. In the Nigerian, Pakistan and Bangladesh national survey, prevalence of blindness was very low in the 10-15 and 30-39 age categories, but increased exponentially from 40 years and above.

Information about the population of Ogun state was obtained from the website of the National population commission, Ogun state official website (Central department of statistics) and the United Nations population fund (UNFPA). Ethical approval was given from the ethics committee of the OOUTH Sagamu. Also approval was sought and obtained before collecting data from various hospital heads of department and units.

\section{Results}

Hospitals that gave cataract surgical services in the state officially are 6 government hospitals, one NGO/Mission eye hospital, one NGO/Private eye hospital and one private hospital and 2 private clinics, but only 4 of the government hospital agreed to participate in this study as shown in Table 1. A total of 8660 eyes in this study during the one year period were identified as having age-related cataracts and 5410 surgeries (eyes) were done. The estimated population of Ogun state in 2014 was 4,924,929. The CSR for Ogun state for this period was (5410/4.94) 1098 operations/million/year (Table 2).

Table 1: Eye Foundation Centre is NGO/Private, State hospital ljebu-ode is state government, St Mary catholic eye hospital is NGO/Mission.

\begin{tabular}{|c|l|l|l|}
\hline $\begin{array}{c}\text { Divisi } \\
\text { ons }\end{array}$ & Hospitals & Ownership & Number \\
\hline Egba & $\begin{array}{l}\text { Federal Medical Centre, } \\
\text { State Hospital Abeokuta }\end{array}$ & Government & 2 \\
\hline Yewa & $\begin{array}{l}\text { State Hospital, Ilaro State } \\
\text { Hospital, Ota }\end{array}$ & Government & 2 \\
\hline \multirow{2}{*}{ ljebu } & $\begin{array}{l}\text { Eye Foundation Centre } \\
\text { State Hospital ljebu-Ode }\end{array}$ & $\begin{array}{l}\text { St Mary's Catholic Eye } \\
\text { Hospital }\end{array}$ & $\begin{array}{l}\text { Government/ } \\
\text { NGO/Mission }\end{array}$ \\
\hline \multirow{2}{*}{ Remo } & $\begin{array}{l}\text { Olabisi Onabanjo } \\
\text { University Teaching }\end{array}$ & $\begin{array}{l}\text { Government/ } \\
\text { Private }\end{array}$ & 2 \\
\hline
\end{tabular}

\begin{tabular}{|l|l|l|l|}
\hline & $\begin{array}{l}\text { Hospital (OOUTH) } \\
\text { Babcock Medical Centre }\end{array}$ & \\
\hline
\end{tabular}

The main providers of cataract surgical services in Ogun state are Eye Foundation Centre (EFC) 3099 eyes (57.2\%) and St Mary Catholic Eye Hospital 1951 (36.0\%), totalling 5050 eyes (93.2\%). Others did 360 eyes (6.8\%), (Table 2 ).

Table 2: No of cataracts identified and no of cataract surgeries performed on patients. Aged 40 years and above in 2014.

\begin{tabular}{|c|c|c|c|}
\hline Hospital & $\begin{array}{l}\text { No of cataracts } \\
\text { identified (eyes) }\end{array}$ & $\begin{array}{l}\text { No of } \\
\text { surgeries } \\
\text { performed } \\
\text { (eyes) }\end{array}$ & $\begin{array}{l}\% \quad \text { no } \\
\text { surgeries } \\
\text { performed }\end{array}$ \\
\hline $\begin{array}{l}\text { Eye Foundation } \\
\text { Centre }\end{array}$ & 5087 & 3099 & 57.2 \\
\hline $\begin{array}{l}\text { St Mary's Catholic } \\
\text { Eye Hospital }\end{array}$ & 1979 & 1951 & 36 \\
\hline $\begin{array}{l}\text { State Hospital } \\
\text { Abeokuta }\end{array}$ & 801 & 80 & 1.5 \\
\hline State Hospital Ota & 142 & 128 & 2.5 \\
\hline $\begin{array}{l}\text { State Hospital } \\
\text { llaro }\end{array}$ & 140 & 95 & 1.7 \\
\hline $\begin{array}{l}\text { State Hospital } \\
\text { ljebu-Ode }\end{array}$ & 216 & 19 & 0.4 \\
\hline $\begin{array}{l}\text { Babcock Medical } \\
\text { Centre }\end{array}$ & 295 & 38 & 0.7 \\
\hline total & 8660 & 5410 & $100 \%$ \\
\hline Backlog & 3250 & $5410 / 4.94$ & \\
\hline CSR & & 1098 & \\
\hline
\end{tabular}

There are 18 surgeons in the state but 11 participated in the study as shown in Table 3. Therefore an average of 491 cataract operations is performed by an ophthalmic surgeon per year in Ogun state.

Table 3: Distribution of surgeons by Eye Hospitals/Clinics in Ogun state in 2014 FMC and OOUTH did not participate in the study.

\begin{tabular}{|l|l|}
\hline Hospital & No of eye surgeons \\
\hline Eye Foundation Centre & 4 \\
\hline St Mary's Catholic Eye Hospital & 2 \\
\hline $\begin{array}{l}\text { Olabisi Onabanjo University Teaching } \\
\text { Hospital (OOUTH) }\end{array}$ & 4 \\
\hline Federal Medical Centre (FMC) & 3 \\
\hline State Hospital Abeokuta & 1 \\
\hline State Hospital Ota & 1 \\
\hline State Hospital Ilaro & 1 \\
\hline State Hospital ljebu-Ode & 1 \\
\hline Babcock Medical Centre & 1 \\
\hline
\end{tabular}


For the state government hospitals 80.5 operations per surgeon per year. NGO/Mission (St Mary's catholic eye hospital): 975.5 operations/surgeon/year. NGO/Private (Eye Foundation Centre): 774.5 operations/surgeon/year and Private hospital: 38 operations/surgeon/year. Therefore an average of 491 cataract operations is performed by an ophthalmic surgeon per year in Ogun state as shown in Table 4.

Table 4: Numbers of cataract surgeries per surgeon per year.

\begin{tabular}{|l|l|l|l|}
\hline $\begin{array}{l}\text { Type of Eye } \\
\text { Hospital }\end{array}$ & $\begin{array}{l}\text { No of } \\
\text { surgeons }\end{array}$ & $\begin{array}{l}\text { Total no of } \\
\text { operations }\end{array}$ & $\begin{array}{l}\text { Operations/ } \\
\text { surgeons/year }\end{array}$ \\
\hline Government & 4 & 322 & 80.5 \\
\hline NGO/Mission & 2 & 1951 & 975.5 \\
\hline NGO/Private & 4 & 3099 & 774.7 \\
\hline Private & 1 & 38 & 38 \\
\hline Total & 11 & 5410 & 492 \\
\hline
\end{tabular}

\section{Discussion}

8660 eyes were identified as age related cataract during this period. This is less than 19,696 the estimated number of people blind from cataract in the state. Therefore there is still a good number of cataract blindness not yet identified. Adepoju et al. reported a blind cataract backlog of 7227 for Kwara state in 2009 [17].

A total of 5410 cataract surgeries were performed in the state in 2014, this is more than the estimated incidence for cataract blindness of 4924 for the state. The CSR in this study is 1098: This is slightly more than the 1000 which is an estimate of new cataract blind people (incidence) per million populations per year which is used for planning purpose in developing countries. The CSR in this study (1098) is more than nationally documented CSR of 100-300 in 1997 [17]. But less than 2000 which is the vision 2020 target for Nigeria [8]. The latest study (2011) put the CSR in Nigeria at 400 [8]. This CSR of 1098 is a little similar to 1020, the CSR for Kwara state of Nigeria in 2009 as reported by Adepoju et al. [18]. It is more than the CSR of 400 reported for southern Ethiopia (2010) by Esmael et al. [19] and less than 2210 in Shanghai in 2009 reported by Mingming Zhu et al [7]. Patients with age less than 40 years were excluded: In the Nigerian, Pakistan and Bangladesh national survey, prevalence of blindness was very low in the 10-15 and 30-39 age categories, but increased exponentially from 40 years and above [10,20-22]. There have been increases in cataract surgical activities in the state especially the 2 key eye hospitals that did 93\% of all the age-related cataract surgeries. In a report by Oke SA et al. [20], in 2005 SMCEH did 543 cataract surgeries, Eye Foundation Centre 350 and a government hospital 53. The SMCEH and EFC have established outreach services. The team in the outreach department of the eye hospitals go out in to the communities to screen the eyes of members of the communities for eye diseases and either bus them to the base hospital or they come on their own for cataract surgeries or treatment of other eye diseases.
Another factor in favour of the 2 eye hospitals is sponsorship of cataract surgeries whereby some individuals, organisations, NGOs, multinationals pay for cataract surgeries for the less privileged [23]. SMCEH partners with Christian Blind Mission (CBM). They help the hospital in the area of manpower and consumables. EFC partners with, Hilton Foundation and MTN Foundation in the areas of consumables and equipment. Some of the other hospitals in Ogun state do outreaches but on a lower scale. Secondly, the many types of cataract surgeries now available to patients like the small incision cataract surgery (SICS), phacoemulsification and Femtolaser assisted cataract surgery have helped to better the visual outcome of patients which has encouraged many patients to agree or consent to have cataract surgery done. Thirdly, Eye Foundation Centre has established vision centres in Ilaro and Sagamu and outpatient centre in Ikorodu. These areas help in feeding the base hospital with patients for cataract surgeries and also doctors go to these centres to follow up postoperative patients. It also reduces the transportation of patients who otherwise will have come to the base hospital at great transportation cost to them. The centre has also trained friends of vision (FOV) and community ophthalmic nurses (CONs) in all the 20 local government areas of the state. Fourthly, the 2 key eye hospitals have differential or tier pricing being practised whereby the base hospital is divided into public and private sector. The private sector is technology driven and the cataract surgical services are expensive. The public sector is low cost and it is high volume driven. These factors have helped to reduce the backlog and increase the CSR. The state hospitals do little cataract surgeries because in most cases it is only one ophthalmic surgeon in the hospital who is also bogged down by administrative activities as medical director of the hospital. Significantly there are no outreach departments in these hospitals. They depend only on patients that come on their own. These state and private hospitals will continue to do very little if they depend only on cases that present to the outpatient clinics because of poverty, poor transportation and poor roads and fear of surgery among the populace [20]: these debar them from accessing hospitals on their own. The 2 key eye hospitals should be emulated if they are to do high volume cataract surgeries to be able to cope with backlog and increase CSR in the state. There are very few private eye hospitals in the state and they do very little (average of 50 cataract surgeries each per year (Personal communications).

The eye hospitals or hospitals with eye clinics in the state are evenly distributed average of 2 per each divisions of the state. There are a total of 18 ophthalmic surgeons in the state in the time of the study from the 9 institutions although 11 ophthalmic surgeons from 7 institutions participated in this study. This does not in any way diminish the authenticity of this study because from personal communications, they don't have any outreach centres and only do cases that present in the hospital which are very few. The 2 eye hospitals (EFC and St Mary) do 93\% of all the age-related cataract surgeries in the state. Their operation per surgeon per year is 1750 compared to the government and private hospitals which are 118 operations per surgeon per year. An ophthalmic surgeon performs an average of 492 cataract surgeries per year on the whole. This is very close to the vision 
2020 target of 500 [8] and this is a tremendous improvement form the earlier documented target of 75 [22].

\section{Limitations of This Study}

It cannot be assumed that the number of cataracts identified equals the total number of cataracts in Ogun state. Taking in to consideration the 19,699 blinding cataract calculated in the introduction. There might have been under reporting or cases of missing data. Or there might have been overestimation of backlog.

Two government hospitals did not take part in this study. Same as the private practitioners, though they are very few. Patients who seek cataract services in neighbouring states e.g. those residing near the border are not taken in to consideration. The research did not consult patients. The study cannot answer question on impact on patient care. In spite of these circumstances, the study gave a good account of Impact of Cataract Surgical Services in Ogun State, Nigeria.

\section{Conclusion}

Although the CSR in Ogun state is slightly more than the target set for cataract incidence in developing countries, there is still a lot of backlog to be cleared. With more effort, cataract backlog will be significantly reduced. There is need for coordinated effort among all stake holders in the state to have a coordinated cataract intervention programme for a wide cataract surgical coverage.

\section{Recommendation}

How to sustain and surpass the current figures: There is need to maintain the present momentum year in year out so that the stage can be reached in which cataract surgeries done per year doubles the incidence of cataract surgeries per year. In this way the backlog of cataract surgeries can be cleared in the state. Collaborations with NGOs must be sustained for a long time to create room for sustainability. Public private partnership is very important for better sustainability in addition to grassroots insurance to enable more people in the community to access hospital facilities.

How to uplift the various low performing centres: Establishment of outreach department with the full complement of staff so that the nooks and crannies of the state where majority of the age related cataract cases reside are screened consistently and bussed to various base hospitals for surgery [23].

Need for state hospitals where there is only one ophthalmic surgeon to have a resident or another ophthalmologist to be able to organise camps effectively and do more cataract surgeries. Need for the establishment of vision centres and outpatient centres to act as centres that are closer to the communities which can act as referral centres to send patients to base hospitals for surgeries and further treatment. And follow-up centres to see patients to curb low follow-up rates at the base hospital.
Conversion to small incision cataract surgery (SICS) and phacoemulsification will increase will increase the quality of visual acuity and hence make people to be attracted to doing their cataract surgery. Tier and differential prices whereby both the rich and poor can choose the services they can afford. The money from the private sector can be used to sustain the public sector.

Collaboration with NGOs and multinationals: as part of corporate social responsibility. More indigent patients will have access to cataract surgeries.

\section{Acknowledgement}

The authors wish to thank the participating hospitals most especially the medical directors for letting us use their data. Also many thanks to all the ophthalmic surgeons in Ogun state.

\section{References}

1. http://bjo.bmj.com/content/early/2011/11/30/ bjophthalmol-2011-300539

2. http://www.ico.org/

3. Foster A (2001) Cataract and "vision 2020-right to sight" 'initiative. Editorial Br J Ophthalmol 85: 635-637.

4. Apple DJ, Ram J, Foster A, Peng Q (2000) Elimination of cataract blindness: a global perspective entering the new millenium. Surv Ophthalmol 1: S1-196.

5. Odugbo OP, Babalola OE, Regina E (2010) Morgan Cataract backlog and output of cataract surgery in Plateau state, Nigeria. J Med Trop 14: 1-6.

6. Zhu M (2014) Four-year analysis of cataract surgery rates in Shanghai, China: a retrospective cross-sectional study. BMC Ophthalmol 14: 3 .

7. Palmer JJ, Chinanayi $F(2014)$ Mapping human resources for eye health in 21 countries of sub-Saharan Africa: current progress towards VISION 2020. Human Resources for Health 44: 12-44.

8. https://collaboration.worldbank.org/docs/DOC-11625

9. Rabiu MM, Kyari F, Ezelum C, Elhassan E, Sanda S, et al. (2012) Review of the publications of the Nigeria national blindness survey: Methodology, prevalence, causes of blindness and visual impairment and outcome of cataract surgery. Ann Afr Med 11: $125-30$

10. www.ogunstate.gov.ng/population-figures

11. www.nigeriamasterweb.com/Nigeria06censusng

12. www.tradingeconomics.com/National bureau of statistics.

13. Nigeria.unfpa.org/ogun.html

14. www.icoph.org/downloads/HiltonFoundationGrantSummary.pdf

15. Akinsete EO (1998) Efficient Surgical service for cataract in Nigeria. Nigeria J. Ophthalmol 6: 16 -19.

16. Adepoju FG, Patel D, Ayanniyi AA, Adekoya BJ , Omolase CO, et al. (2014) Cataract Surgical Services in Kwara State, Nigeria. British Journal of Medicine \& Medical Research 4: 3743-3754.

17. Ali EH (2013) Cataract Surgery Services: A situational Analysis in Southern Ethiopia. BMC Health Serv Res 13: 480. 
18. Oke SA (2007) Analysis of cataract services by eye care provider in Nigeria. Community Eye Health 20: 15.

19. Jadoon Z, Dineen B, Bourne RRA, Shah SP, Khan A, et al. (2006) On behalf of the Pakistan National Eye Survey Study Group. Prevalence of blindness and visual impairment in Pakistan. The Pakistan National Blindness and Visual impairment Survey. Invest Ophth Vis Sci 47: 749-755.

20. Dineen BP, Bourne RR, Ali SM, Huq DM, Johnson GJ (2003) Prevalence and causes of blindness and visual impairment in Bangladeshi adults: results of the National Blindness and Low Vision Survey of Bangladesh. Br J Ophthalmol 87: 820-828.
21. http://www.iapb.org/sites/iapb.org/files/Increasing\%20Cataract \%20Surgical\%20Rate\%20in\%20Nigeria_Eye\%20Foundation \%20Centre_0.pdf

22. Ezepue UF (1993) The problem of cataract backlog in Anambra and Enugu states of Nigeria. A solution in community outreach services. Nig. Journal of Ophthalmol 2: 21-28.

23. Babalola OE (1998) Nigerian ophthalmology and its Aravind model. Nig J of Ophthalmol 6: 16-19. 